\title{
Perancangan Game Math Adventure Sebagai Media Pembelajaran Matematika Berbasis Android
}

\author{
Muhammad Rizky Rahadi $^{1)}$, Kodrat Iman.Satoto ${ }^{2)}$, Ike Pertiwi Windasari ${ }^{2)}$ \\ Jurusan Teknik Sistem Komputer Universitas Diponegoro Semarang \\ Jalan Prof. Sudharto, SH., Kampus UNDIP Tembalang, Semarang 50275, Indonesia \\ email:mrrahadi@gmail.com
}

\begin{abstract}
Abstrak - Upaya meningkatkan efisiensi penyediaan aplikasi yang mengandung unsur pendidikan diperlukan berbagai alternatif dan inovasi baru dalam hal pemrograman untuk bisa diterapkan sebagai alat untuk mempermudah proses pembelajaran. Adanya game edukasi matematika ini diharapkan dapat meningkatkan kemampuan berhitung anak dalam proses pembelajaran matematika, dan menghilangkan rasa jenuh dan takut bagi anak-anak untuk belajar matematika. Game edukasi ini sangat berguna dibidang pendidikan khususnya matematika. Penulis memilih anak berusia 6 tahun sampai 9 tahun sebagai pengguna dalam game edukasi ini, karena akan lebih efektif jika mulai belajar matematika dari kecil karena di usia itulah anak-anak bisa dengan mudah mengingat dalam belajar menghitung.

Metodologi yang digunakan dalam penelitian ini adalah Multimedia Development Life Cycle (MDLC) yang bersumber dari Luther dan sudah dimodifikasi oleh Sutopo. Alat bantu yang digunakan untuk menganalisis penyusun menggunakan Unified Modeling Language (UML). Sedangkan aplikasi yang digunakan dalam pembuatam skripsi ini adalah construct 2.

Penerapan game edukasi matematika ini diharapkan dapat mengatasi masalah tersebut. Jadi disaat anak memainkan game ini anak tidak bosan dan tidak takut untuk belajar matematika, dengan harapan semangat anak untuk belajar akan lebih terpacu dan meningkatkan kualitas belajar anak. Untuk game edukasi ini sendiri diharapkan dapat dikembangkan lagi dalam hal animasi, desain, fitur, dan music sehingga menjadi semakin atraktif.
\end{abstract}

Kata Kunci : Android, Edukasi, Construct 2

\section{PENDAHULUAN}

Matematika adalah studi besaran, struktur, ruang, dan perubahan. Matematika paling banyak digunakan untuk menghitung berbagai nilai besaran. Matematika akan lebih mudah diajarkan pada anak sejak usia dini. Seperti kata pepatah, belajar di waktu kecil bagai mengukir di atas batu, belajar sesudah dewasa serupa mengukir di atas air. Begitu juga halnya ketika belajar matematika yang memang akan lebih efektif jika mulai belajar matematika dari kecil karena di usia itulah anak-anak bisa dengan mudah mengingat dalam belajar menghitung.

Untuk daya tangkap pembelajaran yang baik pada saat ini atau sebelumnya lebih ditekankan kepada pendidikan visual yang terlihat menarik dengan tambahan gambar dan suara. Kebanyakan orang sangat sulit belajar matematika dan menjadi momok dalam belajar. Jika ini bertujuan untuk memudahkan pembelajaran matematika, penting untuk mempelajari secara seimbang keempat operasional dasar.
Penjumlahan, pengurangan, perkalian dan pembagian adalah operasional matematika dasar yang diperlukan untuk belajar matematika.

Melalui penelitian ini, penulis bermaksud membangun aplikasi multimedia pembelajaran interaktif bertema matematika, untuk mengenalkan matematika kepada anak-anak khususnya usia 6-9 tahun dengan cara yang menyenangkan dan mudah diserap pada media perangkat seluler. Untuk itu, dengan dilakukannya penelitian ini, diharapkan dapat menjadi salah satu media pembelajaran matematika yang menyenangkan dan mudah dipahami bagi anak-anak sehingga anak-anak yang dewasa ini kerap menggunakan gadget tidak hanya menggunakannya untuk bermain permainan umum, melainkan ada unsur pendidikan di dalamnya.

\section{A. Pengertian Game}

Game adalah salah satu jenis aktivitas bermain, yang di dalamnya dilakukan dalam konteks berpura-pura namun terlihat seperti realitas. Dimana pemainnya memiliki tujuan untuk mendapatkan satu kemenangan serta dilakukan dengan sesuai aturan permainan yang dibuat

\section{B. $\quad$ Sistem Operasi Android}

Android adalah sistem operasi yang berbasis Linux untuk telepon seluler seperti telepon pintar dan komputer tablet. Android menyediakan platform terbuka bagi para pengembang untuk menciptakan aplikasi mereka sendiri untuk digunakan oleh bermacam piranti bergerak.

\section{C. $\quad$ Unified Modelling Language (UML)}

Unified Modeling Language (UML) digunakan untuk melakukan pemodelan sistem/perangkat lunak dengan menggunakan tools yang ada. Dengan pemodelan menggunakan UML, rekayasa dan pengembangan perangkat dapat dilakukan dengan fokus pengembangan dan desain perangkat lunak terhadap :

1. Tinjauan umum bagaimana arsitektur sistem secara keseluruhan. 
2. Penelaah bagaimana objek-objek dalam sistem saling mengirimkan pesan (message) dan saling bekerjasama satu sama lain.

3. Menguji apakah sistem/perangkat lunak sudah berfungsi seperti yang seharusnya.

4. Dokumentasi sistem/perangkat lunak untuk keperluan-keperluan tertentu di masa yang akan datang

\section{D. $\quad$ Construct 2}

Construct 2 adalah sebuah tool berbasis HTML5 untuk menciptakan sebuah permainan. Dengan tool Construct 2 memungkinkan siapa saja membuat game tanpa harus memiliki pengalaman pemrograman. Dikembangkan oleh Scirra Ltd, hal ini ditujukan terutama untuk para nonprogrammer yang ingin menciptakan sebuah game secara drag and drop menggunakan editor visual dan berbasis sistem logika perilaku.

\section{E. $\quad$ Corel Draw X5}

Corel Draw adalah sebuah program komputer yang melakukan editing pada garis vektor. Program ini dibuat oleh Corel, sebuah perusahaan software yang berkantor pusat di Ottawa, Kanada. Corel draw memiliki kegunaan untuk mengolah gambar, oleh karena itu banyak digunakan pada pekerjaan dalam bidang publikasi atau percetakan ataupun pekerjaan di bidang lain yang membutuhkan proses visualisasi.

\section{F. Tahap Pengembangan Sistem}

Metodologi yang digunakan dalam penelitian ini adalah Multimedia Development Life Cycle (MDLC) yang bersumber dari Luther dan sudah dimodifikasi oleh Sutopo. Metodologi pengembangan multimedia tersebut terdiri dari enam tahap, yaitu konsep (concept), desain (design), pengumpulan materi (material collecting), pembuatan (assembly), pengujian (testing), dan distribusi (distribution). Keenam tahap ini tidak harus berurutan dalam prakteknya, tahap-tahap tersebut dapat saling bertukar posisi.

Metodologi pengembangan multimedia Luther yang telah dimodifikasi oleh Sutopo ini dapat dilihat pada gambar 1

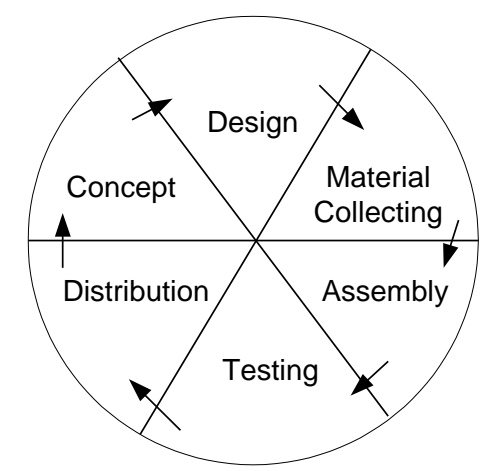

Gambar 1 Tahap pengembangan multimedia menurut Luther yang sudah dimodifikasi oleh Sutopo

\section{A. Konsep \\ III. PERANCANGAN SISTEM \\ Aplikasi yang dibuat dalam penelitian akhir ini} bertujuan untuk mengembangkan sebuah aplikasi multimedia perangkat selular yang dapat menjadi sarana pengenalan dan pembelajaran matematika bagi anak-anak kelas 1 sampai dengan kelas 3 sekolah dasar.

Konsep dasar aplikasi ini yaitu menarik dan mengenalkan dasar-dasar matematika. Oleh sebab itu digunakan perpaduan teks, suara dan gambar dalam merancang desain aplikasi. Permainan Edukatif Math Adventure ini menampilkan game berbentuk petualangan di mana pengguna mengendalikan seorang tokoh yang mengikuti sebuah alur cerita dengan menghadapi berbagai tantangan dan teka-teki, sedangkan untuk unsur edukasi yang akan diterapkan pada game edukasi matematika ini adalah pengguna akan diberikan pertanyaan dan pengguna harus menjawab pertanyaan dengan benar.

\section{B.Desain}

Desain proses dibuat berdasarkan kebutuhan fungsional dan kebutuhan data. Aliran system digambarkan dengan menggunakan UML (Unified Modelling Language).

Diagram UML yang digunakan antara lain diagram use case dan diagram sequence. Diagram use case menggambarkan fungsionalitas yang ditawarkan oleh system dan interaksi antara pengguna dengan system. Diagram sequence menggambarkan bagaimana objek saling berhubungan satu sama lain yang digambarkan sebagai rangkaian langkah-langkah yang dilakukan untuk menghasilkan keluaran tertentu.

Storyboard layout 1 menunjukkan rancangan tampilan pada halaman awal aplikasi ditunjukkan pada gambar 2.

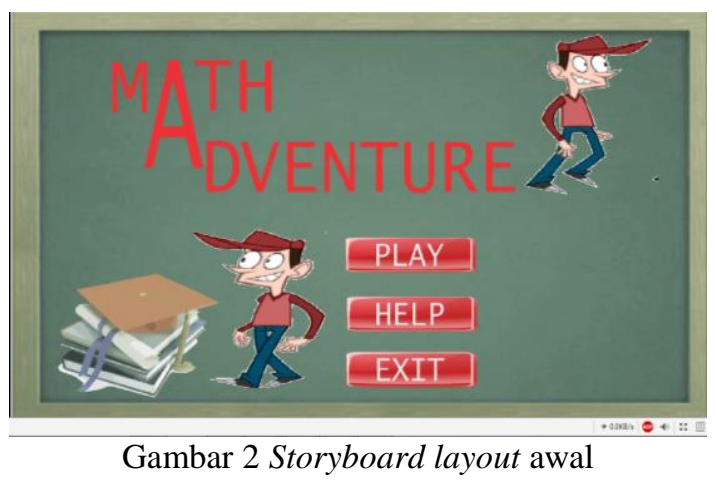

Storyboard layout 2 menunjukkan rancangan tampilan pada halaman help aplikasi ditunjukkan pada gambar 3. 


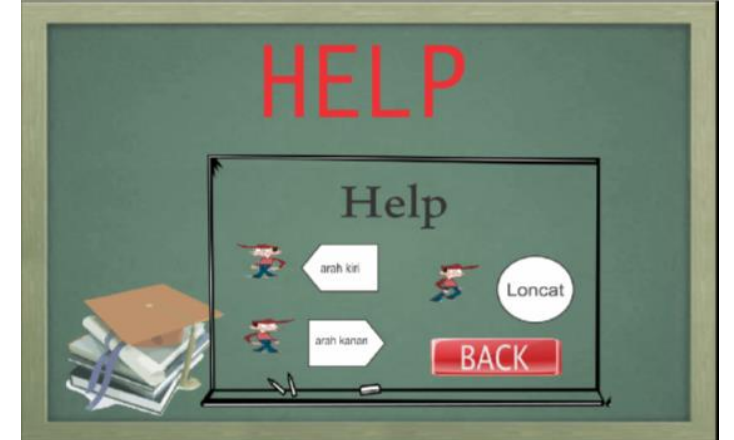

Gambar 3 Storyboard layout help

Storyboard layout 3 yang menunjukkan rancangan tampilan pada menu play ditunjukkan oleh gambar 4.

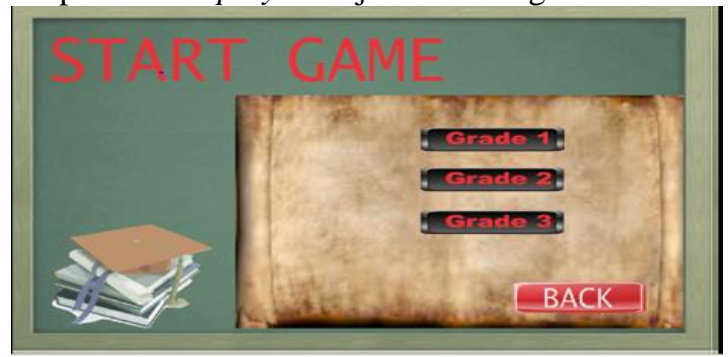

Gambar 4 Storyboard layout play

Storyboard layout 4 yang menunjukkan rancangan tampilan grade 1 ditunjukkan oleh gambar 5.

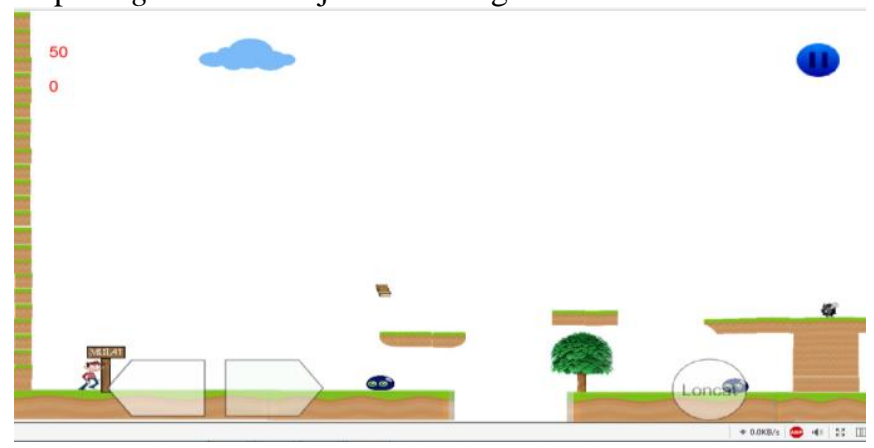

Gambar 5 Storyboard Grade 1

Storyboard layout 5 yang menunjukkan rancangan tampilan pada menu grade 2 ditunjukkan oleh gambar 6 .

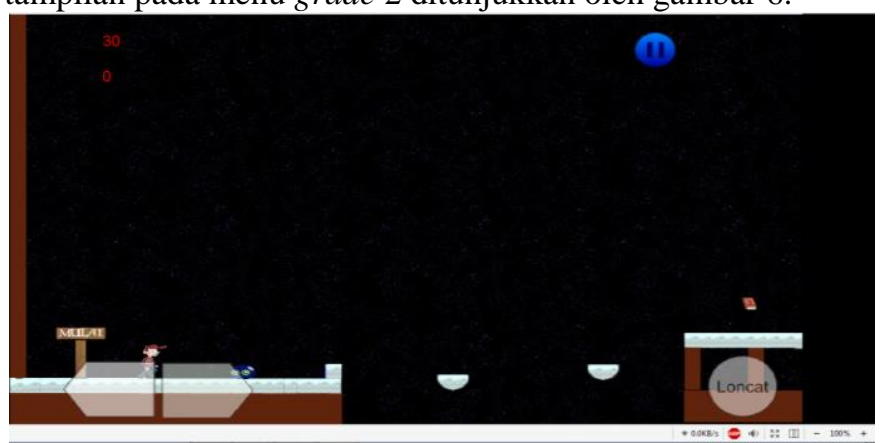

Gambar 6 Storyboard Grade 2

Storyboard layout 6 yang menunjukkan rancangan tampilan pada menu grade 3 ditunjukkan oleh gambar 7 .

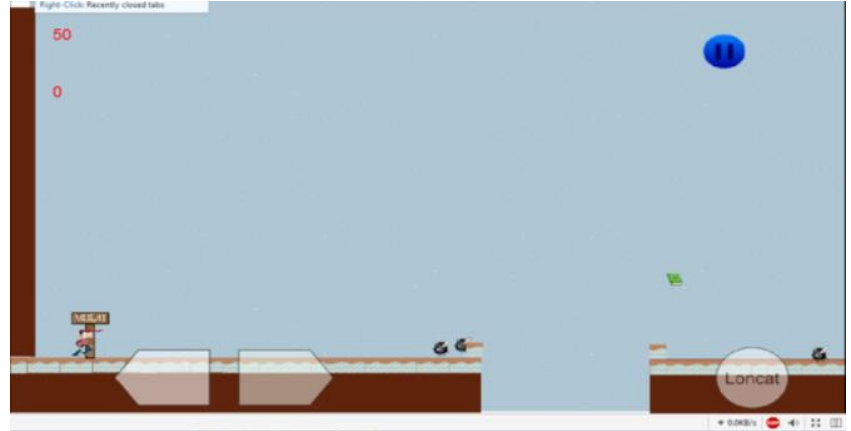

Gambar 7 Storyboard Grade 3

\section{Pengujian Sistem}

Pada bab ini akan dilakukan pengujian terhadap aplikasi permainan hasil pengujian yatu Game Edukasi Matematika tahap ini dilakukan setelah tahap perancangan selesai dilakukan. Adapun hasil dari perancangan tersebut kemudian dianalisa pada smartphone yang sudah ditentukan.

\section{A. Implementasi Antarmuka}

Implementasi antar muka merupakan tahap di mana sebuah sistem siap dioperasikan pada tahap yang sebenarnya, sehingga bisa diketahui apakah sistem yang telah dibuat ini sudah sesuai dengan apa yang sudah dirancang sebelumnya.

\section{Tampilan Menu Awal Game}

Ini merupakan tampilan menu awal game Math Adventure pemain dapat memulai permainan dengan memilih menu play atau dapat juga memilih menu help untuk melihat petunjuk permainan. Tampilan menu awal game dapat dilihat pada gambar 8 .

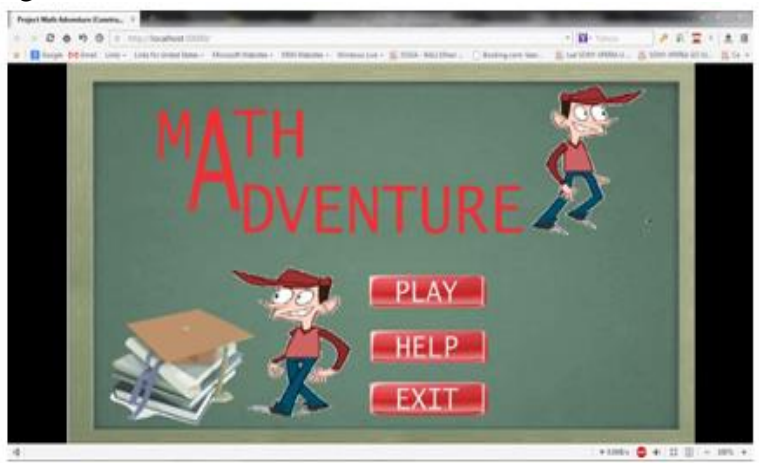

Gambar 8 Tampilan menu awal game

2. Tampilan Menu Help

Tampilan petunjuk cara bermain yang berisi tentang cara memainkan permainan. Tampilan menu help dapat dilihat pada gambar 9 . 


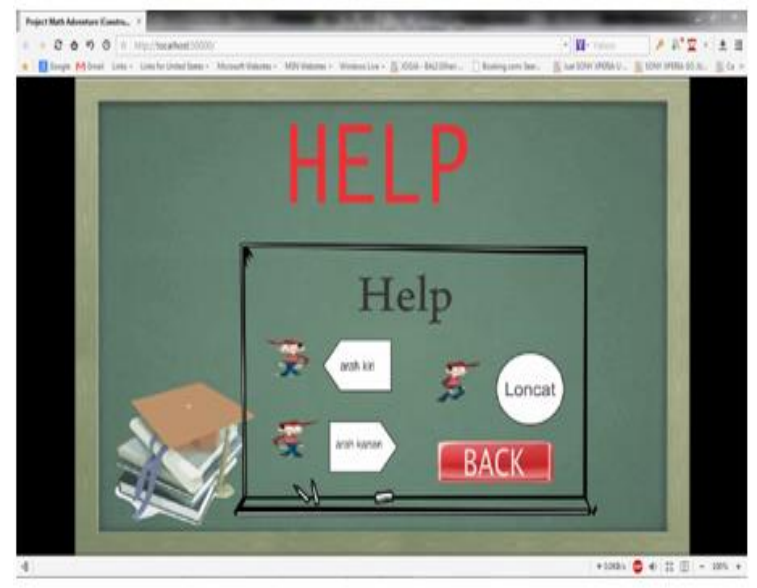

Gambar 9 Tampilan menu help

2. Tampilan Menu Start Game

Tampilan ini dapat diakses jika pemain memilih menu start game. Akan menampilkan memilih level yang pemain ingin mainkan. Tampilan start game dapat dilihat pada gambar 10 .

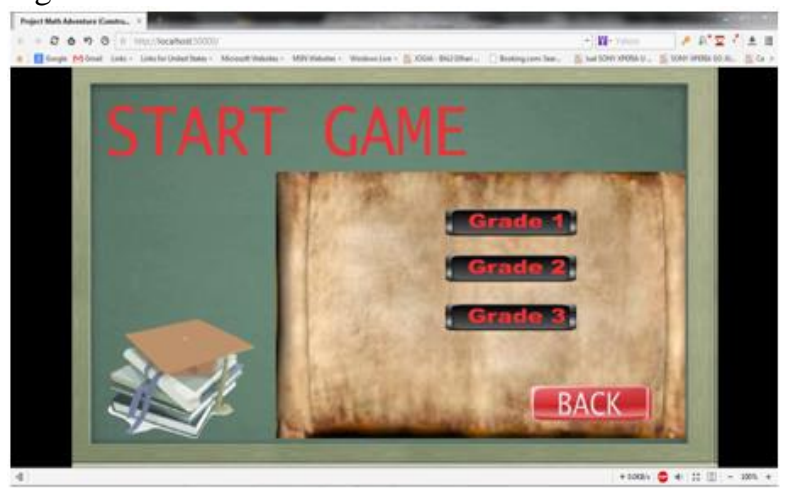

Gambar 10 Tampilan menu start game

\section{Tampilan Grade 1}

Tahap selanjutnya yaitu pembuatan layout grade 1 yang menampilkan permainan petualangan dengan menghadapi musuh-musuh yang, kemudian pengguna juga akan diberikan soal-soal matematika yang harus dijawab. Tampilan grade 1 dapat dilihat pada gambar 11.

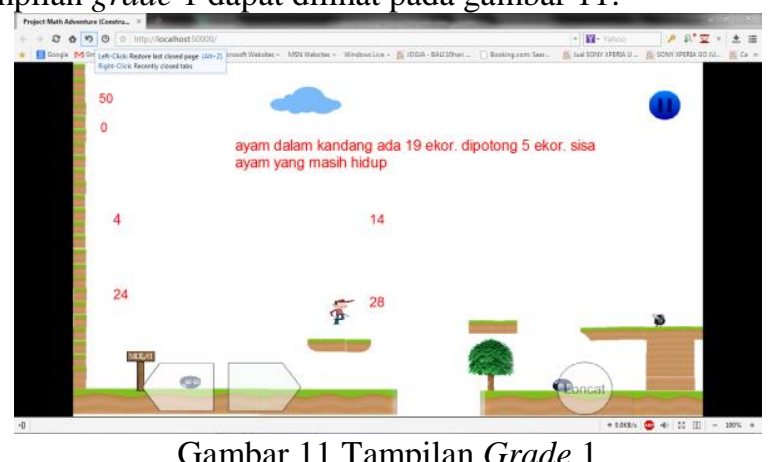

Gambar 11 Tampilan Grade 1

4. Tampilan Grade 2

Tahap selanjutnya yaitu pembuatan layout grade 2 yang menampilkan permainan petualangan dengan menghadapi musuh-musuh yang, kemudian pengguna juga akan diberikan soal-soal matematika yang harus dijawab. Tampilan grade dapat dilihat pada gambar 12 .

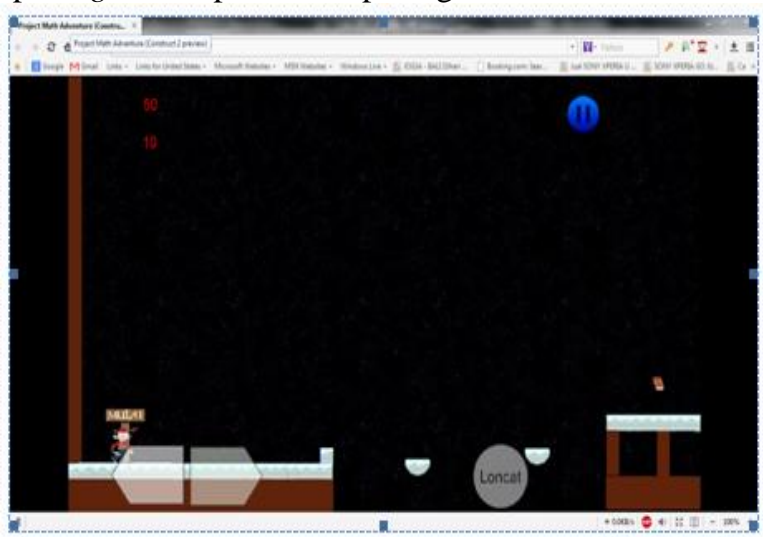

Gambar 12 Tampilan Grade 2

\section{Tampilan Grade 3}

Tahap selanjutnya yaitu pembuatan layout grade 3 yang menampilkan permainan petualangan dengan menghadapi musuh-musuh yang, kemudian pengguna juga akan diberikan soal-soal matematika yang harus dijawab. Tampilan grade 3 dapat dilihat pada gambar 13.

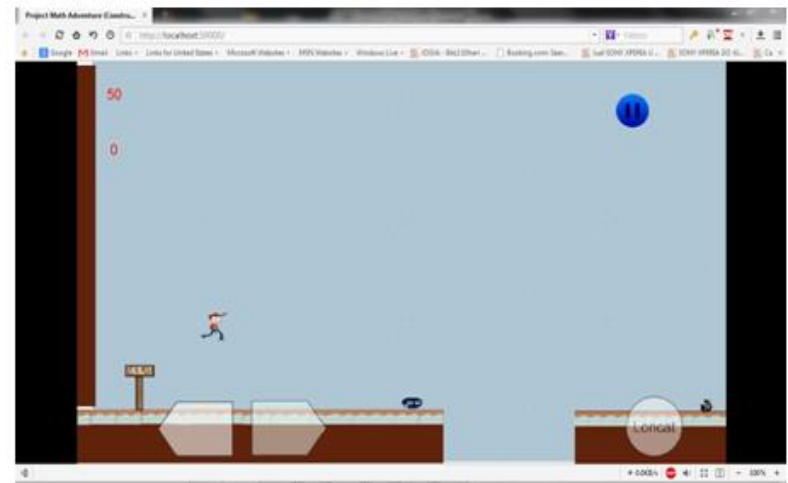

Gambar 13 Tampilan Grade 3

B. Pengujian Black Box

1. Pengujian fungsi umum aplikasi

Berikut tabel pengujian pada fungsi umum aplikasi ditunjukkan oleh tabel 1

Tabel 1 Pengujian Fungsi Umum

\begin{tabular}{|l|l|l|c|}
\hline $\begin{array}{c}\text { Nama } \\
\text { Pengujian }\end{array}$ & \multicolumn{1}{|c|}{$\begin{array}{c}\text { Bentuk } \\
\text { Pengujian }\end{array}$} & $\begin{array}{c}\text { Hasil yang } \\
\text { Diharapkan }\end{array}$ & $\begin{array}{c}\text { Hasil } \\
\text { Pengujian }\end{array}$ \\
\hline $\begin{array}{l}\text { Pengujian } \\
\text { menu mulai }\end{array}$ & $\begin{array}{l}\text { Menyentuh } \\
\text { tombol play }\end{array}$ & $\begin{array}{l}\text { Tampil } \\
\text { halaman } \text { start } \\
\text { game }\end{array}$ & Berhasil \\
\hline $\begin{array}{l}\text { Pengujian } \\
\text { cara } \\
\text { bermain }\end{array}$ & $\begin{array}{l}\text { Menyentuh } \\
\text { tombol } \text { help }\end{array}$ & $\begin{array}{l}\text { Tampil } \\
\text { halaman cara } \\
\text { bermain }\end{array}$ & Berhasil \\
\hline $\begin{array}{l}\text { Pengujian } \\
\text { menu } \\
\text { Keluar }\end{array}$ & $\begin{array}{l}\text { Menyentuh } \\
\text { tombol } \text { exit }\end{array}$ & $\begin{array}{l}\text { Aplikasi } \\
\text { keluar setelah } \\
\text { beberapa detik }\end{array}$ & Berhasil \\
\hline
\end{tabular}

\section{Pengujian Halaman Start Game}

Berikut tabel pengujian pada halaman start game ditunjukkan oleh tabel 2 
Tabel 2 Pengujian Halaman Start Game

\begin{tabular}{|l|l|l|c|}
\hline $\begin{array}{c}\text { Nama } \\
\text { Pengujian }\end{array}$ & \multicolumn{1}{|c|}{$\begin{array}{c}\text { Bentuk } \\
\text { Pengujian }\end{array}$} & $\begin{array}{c}\text { Hasil yang } \\
\text { Diharapkan }\end{array}$ & $\begin{array}{c}\text { Hasil } \\
\text { Pengujian }\end{array}$ \\
\hline $\begin{array}{l}\text { Pengujian } \\
\text { tombol } \\
\text { grade 1 }\end{array}$ & $\begin{array}{l}\text { Menyentuh } \\
\text { tombol } \\
\text { grade 1 }\end{array}$ & $\begin{array}{l}\text { Tampil } \\
\text { halaman } \\
\text { grade 1 }\end{array}$ & Berhasil \\
\hline $\begin{array}{l}\text { Pengujian } \\
\text { tombol } \\
\text { grade 2 }\end{array}$ & $\begin{array}{l}\text { Menyentuh } \\
\text { tombol } \\
\text { grade 2 }\end{array}$ & $\begin{array}{l}\text { Tampil } \\
\text { halaman } \\
\text { grade 2 }\end{array}$ & Berhasil \\
\hline $\begin{array}{l}\text { Pengujian } \\
\text { tombol } \\
\text { grade 3 }\end{array}$ & $\begin{array}{l}\text { Menyentuh } \\
\text { tombol } \\
\text { grade 3 }\end{array}$ & $\begin{array}{l}\text { Tampil } \\
\text { halaman } \\
\text { grade 3 }\end{array}$ & Berhasil \\
\hline $\begin{array}{l}\text { Pengujian } \\
\text { tombol back }\end{array}$ & $\begin{array}{l}\text { Menyentuh } \\
\text { tombol back }\end{array}$ & $\begin{array}{l}\text { Tampil } \\
\text { halaman menu } \\
\text { awal aplikasi }\end{array}$ & sil \\
\hline
\end{tabular}

3. Pengujian Halaman Cara Bermain

Berikut tabel pengujian halaman cara bermain ditunjukkan oleh tabel 3

Tabel 3 Pengujian halaman cara bermain

\begin{tabular}{|l|l|l|c|}
\hline \multicolumn{1}{|c|}{$\begin{array}{c}\text { Nama } \\
\text { Pengujian }\end{array}$} & $\begin{array}{c}\text { Bentuk } \\
\text { Pengujian }\end{array}$ & $\begin{array}{c}\text { Hasil yang } \\
\text { Diharapkan }\end{array}$ & $\begin{array}{c}\text { Hasil } \\
\text { Pengujian }\end{array}$ \\
\hline $\begin{array}{l}\text { Pengujian } \\
\text { cara } \\
\text { bermain }\end{array}$ & $\begin{array}{l}\text { Menyentuh } \\
\text { tombol help }\end{array}$ & $\begin{array}{l}\text { Tampil } \\
\text { halaman cara } \\
\text { bermain }\end{array}$ & Berhasil \\
\hline $\begin{array}{l}\text { Pengujian } \\
\text { tombol } \text { back }\end{array}$ & $\begin{array}{l}\text { Menyentuh } \\
\text { tombol back }\end{array}$ & $\begin{array}{l}\text { Tampil } \\
\text { halaman menu } \\
\text { awal aplikasi }\end{array}$ & Berhasil \\
\hline
\end{tabular}

\section{Pengujian Halaman Permainan}

Berikut tabel pengujian halaman permainan ditunjukkan tabel 4

Tabel 4 Pengujian halaman permainan

\begin{tabular}{|c|c|c|c|}
\hline $\begin{array}{c}\text { Nama } \\
\text { Pengujian }\end{array}$ & $\begin{array}{c}\text { Bentuk } \\
\text { Pengujian }\end{array}$ & $\begin{array}{c}\text { Hasil yang } \\
\text { Diharapkan }\end{array}$ & $\begin{array}{c}\text { Hasil } \\
\text { Pengujian }\end{array}$ \\
\hline $\begin{array}{l}\text { Pengujian } \\
\text { tombol } \\
\text { kanan }\end{array}$ & $\begin{array}{l}\text { Menyentuh } \\
\text { tombol kanan }\end{array}$ & $\begin{array}{l}\text { Player } \\
\text { bergerak ke } \\
\text { arah kanan }\end{array}$ & Berhasil \\
\hline $\begin{array}{l}\text { Pengujian } \\
\text { tombol kiri }\end{array}$ & $\begin{array}{l}\text { Menyentuh } \\
\text { tombol kiri }\end{array}$ & $\begin{array}{l}\text { Player } \\
\text { bergerak ke } \\
\text { arah kiri }\end{array}$ & Berhasil \\
\hline $\begin{array}{l}\text { Pengujian } \\
\text { tombol } \\
\text { loncat }\end{array}$ & $\begin{array}{l}\text { Menyentuh } \\
\text { tombol loncat }\end{array}$ & $\begin{array}{l}\text { Player } \\
\text { bergerak } \\
\text { loncat }\end{array}$ & Berhasil \\
\hline $\begin{array}{l}\text { Pengujian } \\
\text { menyentuh } \\
\text { buku } \\
\end{array}$ & $\begin{array}{l}\text { Player } \\
\text { menyentuh } \\
\text { buku }\end{array}$ & $\begin{array}{l}\text { Menampilkan } \\
\text { materi soal } \\
\text { kuis }\end{array}$ & Berhasil \\
\hline $\begin{array}{l}\text { Pengujian } \\
\text { materi soal } \\
\text { kuis }\end{array}$ & $\begin{array}{l}\text { Menampilkan } \\
\text { soal jika } \\
\text { jawaban benar } \\
\text { mendapat } \\
\text { tambahan nilai } \\
\text { 10, jika salah } \\
\text { mendapat nilai } \\
0\end{array}$ & $\begin{array}{l}\text { Informasi soal } \\
\text { tampil } \\
\text { jawaban benar } \\
10 \text { dan } \\
\text { jawaban salah } \\
0\end{array}$ & Berhasil \\
\hline $\begin{array}{l}\text { Pengujian } \\
\text { tombol } \\
\text { puase }\end{array}$ & $\begin{array}{l}\text { Menyentuh } \\
\text { tombol pause }\end{array}$ & $\begin{array}{l}\text { Menampilkan } \\
\text { halaman } \\
\text { pause dan }\end{array}$ & Berhasil \\
\hline
\end{tabular}

\begin{tabular}{|l|l|l|l|}
\hline & & $\begin{array}{l}\text { permainan } \\
\text { berhenti }\end{array}$ & \\
\hline $\begin{array}{l}\text { Pengujian } \\
\text { player } \\
\text { menyentuh } \\
\text { musuh }\end{array}$ & $\begin{array}{l}\text { Player } \\
\text { menyentuh } \\
\text { musuh yang } \\
\text { ada dalam } \\
\text { permaianan }\end{array}$ & $\begin{array}{l}\text { Nyawa } \\
\text { berkurang 10 } \\
\text { dan player } \\
\text { mengulangi } \\
\text { kembali ke } \\
\text { start point }\end{array}$ & Berhasil \\
\hline $\begin{array}{l}\text { Pengujian } \\
\text { player out } \\
\text { of layout }\end{array}$ & $\begin{array}{l}\text { Player keluar } \\
\text { dari halaman } \\
\text { permaian }\end{array}$ & $\begin{array}{l}\text { Nyawa } \\
\text { berkurang 10 } \\
\text { dan player } \\
\text { mengulangi } \\
\text { kembali ke } \\
\text { start point }\end{array}$ & Berhasil \\
\hline $\begin{array}{l}\text { Pengujian } \\
\text { Game Over }\end{array}$ & $\begin{array}{l}\text { Player } \\
\text { kehabisan } \\
\text { nyawa. }\end{array}$ & $\begin{array}{l}\text { Menampilkan } \\
\text { halaman game } \\
\text { over }\end{array}$ & Berhasil \\
\hline $\begin{array}{l}\text { Pengujian } \\
\text { cek point }\end{array}$ & $\begin{array}{l}\text { Player } \\
\text { mencapai titik } \\
\text { akhir dari } \\
\text { permainan }\end{array}$ & $\begin{array}{l}\text { Menampilkan } \\
\text { halaman akhir } \\
\text { permainan }\end{array}$ & Berhasil \\
\hline
\end{tabular}

$5 \quad$ Pengujian Pause Menu

tabel 5.

Berikut tabel pengujian pause menu ditunjukkan

Tabel 5 Pengujian Pause Menu

\begin{tabular}{|l|l|l|c|}
\hline \multicolumn{1}{|c|}{$\begin{array}{c}\text { Nama } \\
\text { Pengujian }\end{array}$} & $\begin{array}{c}\text { Bentuk } \\
\text { Pengujian }\end{array}$ & $\begin{array}{c}\text { Hasil yang } \\
\text { Diharapkan }\end{array}$ & $\begin{array}{c}\text { Hasil } \\
\text { Pengujian }\end{array}$ \\
\hline $\begin{array}{l}\text { Pengujian } \\
\text { melanjutkan } \\
\text { permainan }\end{array}$ & $\begin{array}{l}\text { Menyentuh } \\
\text { tombol } \\
\text { play }\end{array}$ & $\begin{array}{l}\text { Permainan } \\
\text { kembali } \\
\text { bergerak } \\
\text { normal }\end{array}$ & Berhasil \\
\hline $\begin{array}{l}\text { Pengujian } \\
\text { bantuan } \\
\text { permainan }\end{array}$ & $\begin{array}{l}\text { Menyentuh } \\
\text { tombol } \\
\text { help }\end{array}$ & $\begin{array}{l}\text { Menampilkan } \\
\text { halaman } \\
\text { bantuan } \\
\text { permaianan }\end{array}$ & Berhasil \\
\hline $\begin{array}{l}\text { Pengujian } \\
\text { mengakhiri } \\
\text { permaianan }\end{array}$ & $\begin{array}{l}\text { Menyentuh } \\
\text { tombol } \text { exit }\end{array}$ & $\begin{array}{l}\text { Menampilkan } \\
\text { halaman awal } \\
\text { aplikasi }\end{array}$ & Berhasil \\
\hline
\end{tabular}

\section{Analisis dan Pengujian Pada Smartphone}

Analisis dan pengujian yang dilakukan adalah dengan memsang game Math Adventure di smartphone. Tujuan dari pengujian ini adalah untuk menguji hasil implementasi pada smartphone, apakah sesuai atau dapat diterapkan di masingmasing resolusi smartphone.

1. Analisis dan Pengujian Pada Smartphone Asus Zenfone 5

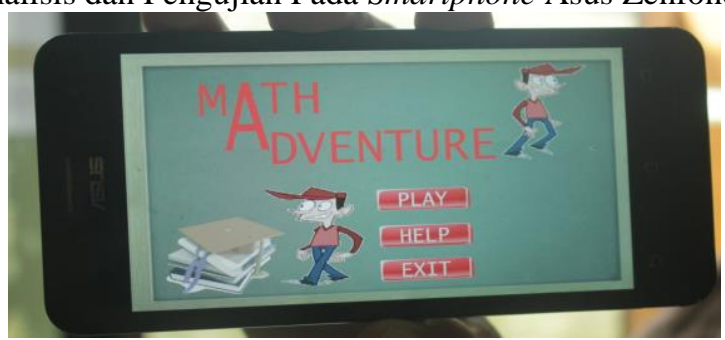


Gambar 14 Impementasi pada Smartphone Asus Zenfone 5

Tabel 6 Spesifikasi Smartphone Asus Zenfone 5

\begin{tabular}{|c|c|}
\hline Spesifikasi & Keterangan \\
\hline Resolusi & $720 \times 1280$ pixels \\
\hline Sistem Operasi & Android OS, v4.4.2 (Jelly Bean) \\
\hline Memori & $2 \mathrm{~GB}$ \\
\hline
\end{tabular}

Pada pengujian di atas, hasil yang didapatkan sudah sesuai dengan pengujian hasil black box. Untuk resolusi 720x1280 pixels dengan system operasi Android v4.4.2 (Jelly Bean) dan memori 2GB RAM sudah dapat berjalan dengan lancar.

\section{PENUTUP}

\section{A. Kesimpulan}

Dari hasil pengujian dan analisis permainan edukasi Math Adventure, dapat disimpulkan hal-hal yang diantaranya sebagai berikut.

1) Berdasarkan hasil pengujian aplikasi Math Adventure menggunakan metode black-box seluruh fungsi menu yand ada di dalam aplikasi telah berjalan sesuai dengan fungsinya.

2) Aplikasi Math Adventure dapat dijalankan pada smartphone dengan sistem operasi Android 4.3 (Jelly Bean).

3) Aplikasi Math Adventure dapat berjalan lancar pada kebutuhan sistem dengan memori 2 GB RAM.

4) Berdasarkan hasil pengujian aplikasi Math Adventure menggunakan olahan data kuesioner menunjukkan bahwa 86.5\% keseluruhan daru hasil olah data kuesioner dapat disimpulkan bahwa aplikasi yang dibuat telah memenuhi syarat untuk dianggap baik.

\section{B. Saran}

Sebagai saran yang diberikan dalam pembuatan game Math Adventure ini sebagai berikut.

1) Pembuatan game yang dibuat dapat dikembangkan lebih beragam lagi dalam hal animasi, desain,, fitur, music serta pemrograman yang lebih efektif dan menarik.

2) Pembuatan game yang dibuat dapat dikembangkan lebih detail lagi dalam hal kapasitas objek sehingga dengan kapasitas yang kecil maka tidak memakan banyak memori

\section{DAFTAR PUSTAKA}

[1] Adiwijaya,Mohammad.Perancangan Game Edukasi Platform Belajar Matematika Berbasis Android Menggunakan Construct 2. Skripsi S-1, Universitas Diponegoro, Semarang, 2014.

[2] Ernest, Adams., Fundamentals of Game Design : The Definition of a Game, (Berkeley, CA,New Riders, 2010).

[3] Ivan, C. Sibero., 2009. Langkah-langkah Mudah Membuat Game 3D. Yogyakarta : MediaKom

[4] Nazruddin, S. II., Pemrograman Aplikasi Mobile Smartphone dan Tablet PC berbasis Android, (Bandung : Informatika, 2012)

[5] Nuzul, S. Tri., Pembangunan Game Edukasi Petualangan Objek Wisata Bersejearah di Indonesia Berbasis Desktop, Skripsi S-1, Universitas Komputer Indonesia, Bandung, 2012.

[6] Setiawan, Iwan., PerancanganSoftware Embedded System Berbasis FSM, Semarang 2006

[7] Setiawan,R.F.F.,Pembangunan Game Evaluasi Operasi Matematika Dasar Untuk Siswa Dasar Kelas Tiga, Skripsi S-1, Universitas Surabaya, Surabaya, 2012.

[8] Supardi,Yuniar., Semua bisa jadi menjadi Programmer Android, Jakarta, PT Eex Media Komputindo, 2014.

[9] Construct2 ,http://www.scirra.com [diakses: 02 Agustus 2015]

[10] CorelDraw X5, http://graphicssoft.about.com [diakses: 02 Agustus 2015] 